\title{
THE NATURE AND SCOPE OF THE EXECUTIVE POWER IN ENGLISH AND FRENCH-SPEAKING AFRICA: A COMPARATIVE PERSPECTIVE*
}

\author{
By J. B. OJwANG
}

\section{A. INTRODUCTION}

Although the main problem of constitutional law, namely, the breadth of the Executive Power and the negative effect this might have in relation to individual liberty, is the same in the new as in the older States, it is much more acute in the former than in the latter. In their many years of evolution the older States have been able to evolve stable organs of power which operate on the basis of recognised balancing procedures, and, in some cases, to undertake many beneficial experiments in the light of accepted theories. Thus, for instance, it has been possible in Britain to evolve a constitutional structure which, at least, offers an opportunity for the exercise of mutual restraint among the organs of government. And in the United States the Constitution assigns "all legislative powers . . . [to] a Congress ... ."1, "the executive power [to] a President"2, "the judicial power [to] . . . [a] supreme Court . . ."3; a remarkable experimentation with the Montesquieu formula which draws a clear demarcation between one organ of government and another.

The expanse of the Executive Power in the new States is striking. Unlike the stable nations of the West, the African States, for instance, have generally lacked a base on which to construct liberal institutions of public law; and with their fragile economic structures they have relied on the political leadership, the Executive Authority, for help in the creation of a measure of stability. These States, with their little-developed cohesion of political purpose and the consequent lack of harmony in political motion, have tended to look to the Executive for direction and patronage. In these circumstances, such institutions as are currently evolving will do so under conditions in which the Executive Authority holds a special position of influence. Accordingly, although one may study such institutions in their ow n right as organs of governmental authority, it is important to recognise that none of them, in the framework of public law, could approximate to the Executive organ in terms of power and influence. This argument, if it may be of a broader validity, must carry special force as regards the new States. The aim in this article is to illustrate the general argument raised above through a study of the nature and scope of the Executive Power in Africa. One of the main factors influencing the growth of the institutions under inquiry will be the historical background, in particular, the styles of colonial rule adopted in the various countries prior to the attainment of independence, a phase which was followed by the adoption of western-derived Constitutions. The postindependence constitutional pattern might be expected to bear important resemblances (or some forms of analogy, at any rate) to the bodies of public law from which the transplantation had taken place. But, at the same time, these States might be expected to evolve novel institutions on account of the new problems of politics and of law which would, no doubt,

\footnotetext{
"This article is based on ongoing research for a doctoral degree in the University of Cambridge. The author acknowledges a debt of gratitude to Professor William C. Whitford of the University of Wisconsin Law School, Madison, for his comments on an earlier draft.

1 Art. I, s. 1.

2 Art. II, s. 1.

3 Art. III, s. 1.
} 
confront them as they organised their structures in response to particular goals of development.

One thus notices, with regard to the African States, the presence of important factors of both heterogeneity and homogeneity, the former arising from the different origins of constitutional transplantation, the latter from the common problems of development which would often attract like solutions; the latter form the essential basis of comparability even as the former pose the main challenge to comparative inquiry. Such an investigation, based on a careful selection of countries, might be expected not only to illuminate the general character of African public law but, further, to indicate any issues of priority in the development of this branch of law.

The historical origin of the African States lies in colonisation by western Powers. As the most influential institutional practices on the continent have been those derived from Britain and France, it is almost natural in a comparative study to make one's selection from the two dominant traditions.

In this respect we select Kenya in East Africa and the Ivory Coast in West Africa, the former representing the British influence, the latter the French. These two, further, offer a unique facility to comparative inquiry, that of fairly consistent patterns of development in the last two decades or so. Both attained independence, as we will see, on the basis of derived Constitutions which have been modified with circumspection and exercised with occasional reference to the traditional norms under the original prototypes. Few other African countries have observed such a "reference-relationship".

\section{B. THE HISTORICAL BACKGROUND}

In a study of Executive Power in those parts of Africa which came under European occupation it is necessary to examine, if only briefly, the colonial background against which the new State has emerged. So recent is the phenomenon of the State that, to appreciate its constitutional structure and functioning, one naturally seeks to learn something about its historical and legal foundation. Secondly, in most of these States, the position of the Executive Authority owes just as much to the post-independence political and constitutional developments as it does to the tradition inherited from the era of colonial rule.

\section{KENYA: THE COLONIAL EXECUTIVE MACHINERY}

The effective process of colonising Kenya began in 1888, when the Imperial British East Africa Company was granted a Royal Charter and invested with governmental powers over territory under its influence. The responsibility for government, however, passed to the British Government in 1895 with the declaration of "Protectorate" status in pursuance of international obligations created by the General Act of the Brussels Conference of $1890^{4}$. Further responsibilities were assumed with annexation in 1920, the territory becoming "Kenya Colony". 4 Y. P. Ghai and J. P. W. B. McAuslan, Public Law and Political Change in Kenya (1970), pp. 12-14; H. F. Morris, "Protection or An-
nexation? Some Constitutional Anomalies of Colonial Rule", in H. F. Morris and J. S. Read, Indirect Rule and the Search for Justice (1973), pp. 41-70. 
The Executive machinery was established by a series of imperial subsidiary legislation, commencing with the East Africa Order in Council of $1897^{5}$, which established the office of Commissioner, its occupant to be appointed by the Queen and be responsible for the conduct of government in the territory. The Commissioner was to discharge his responsibility by making "Queen's Regulations", which had the force of law ${ }^{6}$. This basic structure was to be redefined by successive subsidiary legislation in the following years, though without making any fundamental change. The Commissioner, renamed Governor in 1920, remained the law-maker, chief administrator and holder of various prerogatives including that of pardon. His position as legislator and administrator was by no means prejudiced with the establishment in 1906 of the Legislative and Executive Councils ${ }^{7}$. He presided over the sittings of both Councils, had a veto power, and all laws were expressed to be "enacted by the Governor with the advice of the Legislative Council". The Governor also made all senior Judicial appointments, the appointees holding office at the pleasure of the Monarch (in effect the pleasure of the Governor).

The constitutional structure underwent a succession of changes between 1920 and 1963, the main factors being: (i) growing demands for increased representation in the governmental institutions by the various racial groups; (ii) the Second World War, which occasioned a measure of re-organisation; (iii) a rising level of political awareness among the dominant African population in the last decade of colonisation, coinciding with a general move towards independence in other African countries. The interactions of these forces gave rise to new dynamics of constitutional change.

Under the Emergency Powers (Colonial Defence) Order in Council of the United Kingdom of 1939, the Executive Council was empowered to take important decisions outside the framework of debate in the Legislative Council; and this arrangement was to culminate in the "Membership System", a form of Ministerial organisation under which the Departments of Government were separately grouped and placed under the charge of particular "Members" within the Executive Council. Each "Member" was responsible only to the Governor for the conduct of administration in his group of Departments.

The first departure from the "Membership System" came with the "Lyttelton Constitution" of $1954^{8}$, under which a Council of Ministers, a smaller body within the Executive Council, was introduced. In a limited sense the new Council was to operate on the basis of the Westminster constitutional model; it was "the principle instrument of Government" and was required to "exercise a collective responsibility for decisions on Government policy, to support and vote with it in the Legislature and to support that policy in public and in private.". In 1958 the "Lennox-Boyd Constitution"10 was introduced, mainly a s a response to the failure of the earlier Constitution to ease the prevailing racial disharmony. Under this Constitution the structure of the Executive organ was modified, with the abolition of the Executive Council and the enlargement of the Council of Ministers. Although, as before, the function of the Couricil was to advise the Governor on policy and in the exercise of his powers, it was for him alone to take certain reserved categories of decisions ${ }^{\mathbf{1 1}}$. The Governor was given even

\footnotetext{
5 S. I. No. 575 of 1897.

6 Ibid., Arts. 21, 23, 45. See also the East Africa Order in Council, S. I. No. 757 of 1899, Art. II (amending the Order in Council of 1897).

7 East Africa Order in Council 1906, Art. XII.

8 Contained in Additional Instructions, Govt. Notice No. 582 of 1954.

9 Kenya: Proposals for a Reconstruction of the Government (March 1954) (Cmnd. 9103), para. 1. It was a highly limited form of collective ministerial responsibility, however, for not only were most of the Ministers officials, but the Legislature itself was neither independent nor properly representative. See H. V. Wiseman, The Cabinet in the Commonwealth (1958), pp. 88-89.

10 Kenya (Constitution) Order in Council, S. I. No. 600 of 1958.

11 Ibid., Art. 12.
} 
more powers over the Legislative Council, which he could override and give legal validity to any outstanding Bill or Motion in case of delay or non-compliance if he considered such action "reasonable and expedient"12.

Although it by no means decreased the competence of the Governor, the "Lennox-Boyd Constitution" did coincide with a course of events which, by bringing about a gradual decentralisation of power, were to foreshadow the attainment of independence. In 1960 a Constitutional Conference was convened in London, attended by representatives of the various shades of political opinion in Kenya, with the view of arriving at a consensus on the legal form of forthcoming independence. The guiding principle was pronounced by the Conference President, the Secretary of State for Colonial Affairs:

Her Majesty's Government's aim was to build a nation based on parliamentary institutions on the Westminster model and enjoying responsible government under certain traditional conditions ...13

Not only did this principle concede decentralisation of power; even more important, it pointed to the kind of governmental structure which was to be phased in as a basis for independent statehood.

The amended Constitution promulgated following the 1960 Conference, while retaining intact the existing provisions on Executive Power, instituted a potential limitation to their mode of exercise, by way of a justiciable Bill of Rights. Every individual was, henceforth, guaranteed the enjoyment of personal liberty, private family life, freedom of conscience, of expression, of assembly, of private property, etc. ${ }^{14}$ Although there appears to be no case in which any of these provisions was relied upon in litigation while the Constitution remained in force, it may still be argued that, in strict legality, they did impose limits on the exercise of the Executive Power.

But the more striking aspect of the new Constitution was at the "political" level. As the general elections of 1961, held within the terms of the Constitution, had taken place on the basis of political parties, the membership of the Legislative Council was, for the first time, divided on party lines, the stage thus being set for the Westminster style by which Government leadership depended on "political" representation inside the elected Chamber. But this scheme would not work for a while as the largest party, the Kenya African National Union (KANU), would not agree to form a Government in protest against restrictions which were then in force against certain leading African politicians. The second largest party, the Kenya African Democratic Union (KADU), was then invited to form a Government. But this Government, falling one stage below "Internal Self-Government" in the transitional process toward independence, was dominated by the official element and relegated to the periphery in the exercise of real power, the Governor continuing as the effective Executive Authority. A further Constitutional Conference was convened in London in early 1962, for the purpose of reaching an agreement on an Internal Self-Government Constitution. At the end of the day a quasi-federal structure was proposed in which there was to be "a...strong Central Government responsible to the Central Parliament." The Governor was to appoint a Prime Minister on the basis of party representation in the Lower House of the National Assembly $^{15}$. The other Ministers were to be appointed by the Governor acting on the advice of the Prime Minister. The Governor could dismiss the Prime Minister in the event that the Gov-

\footnotetext{
12 Ibid., Art. 41.

13 Report of the Kenya Constitutional Conference-Held in January and February 1960 (Cmnd. 960), para. 9 (emphasis added).

14 Kenya (Constitution) (Amendment No. 2) Order in Council, S. I. No. 2201 of 1960, 4th Sched.

15 Kenya Constitution: Summary of the Proposed Constitution for Internal Self-Government, March 1963 (Gmnd. 1970), Chap. IV, 2nd.
} 
ernment lost a vote of confidence; he could also remove the other Ministers on the advice of the Prime Minister. The Cabinet, presided over by the Prime Minister, advised the Governor on general administration and was collectively responsible to both Houses of Parliament "for everything done by or under the authority of any Minister in the execution of his office ${ }^{16}$."

Although the elected Government, under the Internal Self-Government Constitution, was limited by a Bill of Rights and by a regional structure which devolved certain powers upon provincial bodies, in practice the more important constraint was that afforded by the discretionary oversight of the Governor. As the late Professor S. A. de Smith observed in the early 1960s, Internal Self-Government in the British Empire constantly meant that "The Crown . . . retains full powers of constitutional amendment, and sometimes retains unrestricted legislative powers, exercisable by Order in Council17." Under Kenya's Internal SelfGovernment Constitution, which came into force at the beginning of June 1963, "the Governor, acting in his [own] discretion, [was to] continue to be responsible for defence, including naval, military and air force, external affairs, and internal security . . .18" Thus, in law, the effective powers of the Executive Authority vested in the Governor rather than in the Prime Minister and his Cabinet.

However, for our purpose, the critical aspect of the Internal Self-Government phase was not so much the introduction of a new Constitution with specific provisions relating to the Executive Power as the fact that, for the first time, a politically organised Government, supported by a popularly elected Legislature, had come into being. The general elections of 1963 had been contested on the basis of party politics, KANU winning with an impressive margin and its leader, Jomo Kenyatta, becoming the first Prime Minister. The constitutional order was now being operated by the masses through the vote and by a Government having a popular mandate to take initiative and offer leadership ${ }^{\mathbf{1 9}}$. Kenyatta's re-emergence in political leadership after almost a decade of restriction was a fact which was destined to influence closely the pattern of constitutional development. In these circumstances, although the Governor remained, in title, the holder of the powers of Government, in actual practice he was more likely to rely on the advice of the Prime Minister and his Cabinet than take the risk of making decisions which might be legally justified yet politically unrelished. This reality was given juridical validation under the Independence Constitution of 12 December, $1963^{20}$.

16 Ibid., 3rd para. Such provisions were incorporated in the Kenya (Amendment) Order in Council, S. I. No. 1047 of 1963. The quasifederal structure as well as the second Parliamentary Chamber were to be scrapped and replaced with a unitary power structure in the decade following the attainment of independence.

17 S. A. de Smith, The New Commonwealth and its Constitutions (1964), p. 56.

18 Cmnd. 1970, Chap. IV, 4th para. The Governor was entrusted with other extensive powers too, to enable him to continue to command obedience up to the date of independence. Under the Detained and Restricted Persons (Special Provisions)Ordinance(No. 3 of 1960) he could, in the interests of "public safety and the maintenance of public order", make regulations providing for the detention of persons, the prohibition, restriction and control of movement, control of acquisition and use of property, etc. (s. 3 [1]). By the Preservation of Public Security Ordinance (No. 2 of 1960) he was empowered to make regulations providing for "the prohibition of the publication and dissemination of matter prejudicial to public security, and . . . for the regulation and control of the production, publishing, sale, supply, distribution and pos session of publications" (s. 3 [2][g]); "the prohibition, restriction and control of assemblies" (s. 3 [2][b]); etc. Under the Kenya (Constitution) Temporary Provisions) Order in Council (S. I. No. 835 of 1961), the Governor was invested with a general discretion "to make [special] laws for the peace, order and good government of Kenya" (Art. 2 [1]). This power could be exercised also to amend existing laws: see, for instance, the Civil Contingencies Fund (Temporary Provisions) Ordinance (No. 1 of 1961).

19 G. Arnold, Kenyatta and the Politics of Kenya (1974), p. 160; G. Bennett, Kenya: A Political History (1963), p. 159.

20 Kenya Independence Order in Council, S. I. No. 1968 of 1963, Art. 1. This Constitution was based on the Report of the final London Conference - Kenya: Independence Conference 1963 (Cmnd. 2156). 


\section{IVORY COAST: THE COLONIAL EXECUTIVE MACHINERY}

There appears to have been one striking contrast between the British and the French colonial policy in Africa: whereas Britain often readily entrusted the government of her colonies to Governors and officials, France nearly always maintained a highly centralised administration in which all major decisions were taken in Paris and a close control secured at federal and territorial levels in the overseas possessions ${ }^{21}$.

The French style is to be seen in the context of the rigid administrative structure built up under Napoleon Bonaparte, bequeathed to the Second French Republic and passed on to the later Republics. In this system, known as étatisme, the middle classes, who manned all branches of the Public Service (la fonction publique) and the vital Conseil d'Etat, had evolved an omnipotent governmental structure, the overriding purpose of which has been stated as:

concern for law and order, stable government and good (in the sense of efficient) administration: an impatience with political controversy, conflicting ideologies and interests, and all party divisions: a longing to "lift government out of politics" and provide regular administration by experts ${ }^{22}$.

This explains such phenomena as assimilation, a policy applied in some parts of French-ruled West Africa for as long as a century ${ }^{23}$, and the essence of which consisted in the ideal of equality between Frenchmen and Africans.

Against this background it is understandable that France, in so far as was practicable, invariably governed her colonies as federal entities rather than as individual territories; the colonies being part of the highly centralised structure of authority of Metropolitan France. The colonial background of the Ivory Coast, therefore, must be considered within a federal context; and in this respect it falls into three recognisable phases: (i) from 1893 to 1944; (ii) from 1945 to 1955; and (iii) from 1956 to 1960; each succeeding phase being marked by a modified Constitutional Law, designed to bring about a relative liberalisation in the structure and working of government.

The First Phase. Before 1894, the responsibility for administration in French-ruled West Africa was carried by military personnel in charge of the various outposts, within the framework of the Ministry of the Marine and the Army. No formal constitutional structure existed before 1895, when a loose entity, le Gouvernement général de l'Afrique occidentale, was created to co-ordinate the administration of the eight West African possessions. This structure was given a more definite shape with the establishment of the Fédération de l'Afrique occidentale française (AOF), the Executive Powers of which were vested in a Governor-General, a senior public servant appointed by the President of the Republic. The Governor promulgated all Metropolitan laws intended for the colonies, issued any necessary regulations concerning the application of laws and took all important decisions relating to administration, being supported where necessary by a body of public servants known as the Conseil de Gouvernement. At the territorial level the powers of government vested in the resident Lieutenant Governor, who was in turn advised by the Conseil d'Administration, a body of public servants.

\footnotetext{
21 J. E. Harris, Africans and their History (1972), pp. 162-72; Lord Hailey, An African Survey (1957), p. 206.

22 D. Thomson, Democracy in France since 1870, 5th ed. (1969), pp. 60-61.

23 K. Robinson, "Political development in West Africa", in C. W. Stillman (ed.), Africa in the Modern World (1955), pp. 141-51; T. Hodgkin and R. Schachter, "French-Speaking West Africa in Transition", in International Conciliation, No. 528 (1960), $389-92$.
} 
The Second Phase. The defeat of France in the Second World War gave rise to a re-examination of her colonial policies, with the main concern of opening up the constitutional structure to African participation at various levels, and that of "granting to each Overseas Territory a full political life ${ }^{24}$ ". The most influential of such proposals for change were those associated with the Free French, and articulated in the Brazzaville Resolutions of 1944. Incorporated in the French Constitution of 1946, these proposals did not, however, allow the colonies any significant measure of autonomy or decentralisation of power, as it was considered that such a grant would have been harmful to the unity of the Republic. The new order, much like the old, consisted of a two-tier governmental structure: the President of the Republic, who was also head of the newly-created French Union" ${ }^{25}$, represented "the permanent interests of the Union" and discharged the overall responsibility of government ${ }^{26}$, while the GovernorGeneral, responsible to the Metropolitan authorities, constituted the Executive Authority at the level of the AOF'27.

The Third Phase. Prior to 1946, the nature of political grievance in the AOF could be thus summarised: "The clamour of the Africans resolves into one concept: Equality ${ }^{28}$ ". So long as the system of assimilation facilitated elevation from the status of French subject (sujet français) to that of French citizen (citoyen français) the people of the Overseas Territories were generally indifferent to the existing concentration of governmental powers upon the narrowest base. But once this factor was removed by the Constitution of 1946 (which not only extended citizenship to all people but also guaranteed them the freedoms of assembly, association, expression, etc.) the stage was set for popular demands in the realm of politics, the flood-gates had been flung open ${ }^{29}$. It became more urgent than ever to establish autonomous participatory units of government in the territories if their peoples, thanks to their new legal rights, were not to take a disproportionate share of representation in the governmental institutions of Metropolitan France.

Thus the Mollet Government introduced the well-known Loi-Cadre (1956), making new arrangements for government in the Overseas Territories. The federal level of administration in the AOF was to be phased out and replaced with stronger territorial units based on the Governor and a form of Cabinet, le Conseil de Gouvernement, responsible to a legislative body, l'Assemblée Territoriale ${ }^{30}$. In spite of this new system, however, the Governor remained dominant, certain spheres of decision making being reserved to him alone. Not only did he preside over the meetings of the Conseil; the Governor could also veto decisions of the Assembly if he considered these to be ultra vires or likely to prejudice the national defence, public order, security or civil liberty.

The Fifth Republican Constitution took the process of decentralisation of power further still. The Overseas Territories were each elevated to the status of "Internal Self-Government" (République autonome), with a Constitution providing for government within the ambit of a French Community ${ }^{31}$. Although these Constitutions were of standard form, all based on the French model ${ }^{32}$, most of the territories adopted simpler procedures where this was possible. The Ivory Coast Constitution ${ }^{33}$, for instance, provided for an Executive Au-

\footnotetext{
24 F. Luchaire, Droit d'Outre-mer et de la coopération, 2nd ed. (1966), p. 125.

25 Constitution of the French Republic, 27 October 1946, Art. 64.

26 Ibid., Art. 65.

27 Ibid., Art. 76.

28 Marchés coloniaux du monde, 14 July 1951, p. 1863 - quoted in Lord Hailey, op. cit., p. 212.

29 Luchaire, op. cit., p. 129.

30 P. Lampué, Droit d'Outre-mer et de la coopération, 4 th ed. (1969), p. 73.

31 P.-F. Gonidec, Constitutions des Etats de la Communauté: textes recueillis et présentés (1959).

32 Ibid., p. 6.

33 Constitution of the Republic of the Ivory Coast, 26 March 1959.
} 
thority consisting of a Prime Minister who was also Head of State, and a Cabinet appointed by him. The Government was responsible to a new legislative body, the Assemblée Législative, which could bring it down on a vote of confidence. Like his French counterpart the Prime Minister had a law-making initiative "concurrent with that of the members of the Legislative Assembly ${ }^{34 "}$ ". He also held a broad lawmaking competence within the exclusive Executive domain (le domaine du pouvoir réglementaire) ${ }^{35}$ and could act by ordinance in the exclusive Legislative domain (le domaine de la loi) ${ }^{36}$ if the Legislature consented to this. The Prime Minister's powers were, however, limited by the Community structure which reserved certain areas of competence, namely, foreign affairs, defence, economy and finance, strategic minerals, etc. ${ }^{37}$, to the French President as head of the confederation.

The Community, however, came to an end in 1960, each Overseas Territory becoming a full-fledged independent State. While it lasted the confederation had revealed certain major weaknesses, in particular, it had represented an unequal political and legal relation between France and the Overseas Territories.

\section{SOME COMPARABLE ASPECTS OF THE COLONIAL EXPERIENCES}

In both Kenya and the Ivory Coast the evolution of Executive Power was marked by a concentration of authority in few hands. This feature might be attributed both to common and to specific aspects of the British and the French colonial policy. The overriding purpose of the colonial Powers had been to maintain law and order so as to facilitate the growth of socio-economic infrastructures. To attain this objective a strong and efficient administration with a focus of competence on the narrowest base was considered essential.

In the British possessions it was the constant policy to set up relatively inexpensive control structures which imposed a minimal burden on the imperial Government. The general formula was to vest the Executive Power in a Governor who had an almost unfettered discretion. As Nwabueze notes:

Government was conceived in terms of a centralised authority flowing from the imperial power to a single governor as the sole representative of the monarch for the exercise of the entirety of her powers and jurisdiction within the dependency ${ }^{38}$.

What instructions the British Government did issue were by no means intended to qualify the Governor's supreme authority. It follows that little regard was paid to the concept of control of power; it would appear, indeed, that there was seen to be a need to confer more powers rather than restrict those which were already in force.

If Britain's policy was pragmatic and mainly guided by considerations of cost and convenience, that of France had an ideological character: in the then fashionable precept of étatisme, France and her overseas possessions all belonged together (une République indivisible) and the entire unit was subject to but one chain of administration. This system, like that obtaining in the British colonies, was hardly reconcilable with the idea of control of power as an ideal of constitutional theory. Further, as the real holder of power, the Metropolitan Head of State, was beyond the jurisdiction of the colonial institutions, no control of his powers nor

\footnotetext{
34 Ibid., Art. 11.

35 Ibid., Art. 39.

36 Ibid., A rt. 40.

37 Dalloz, Nouveau répertoire de Droit, 2nd ed. (1962), Vol. 1, pp. 766-67; P.-F. Gonidec, "La Communauté", in Public Law (1960), 177-89; G. Devernois, "Birth and Development of the Franco-African Community", in Civilisations, 9 (2) (1959), 208-22; Lampué, op. cit., pp. 79-85.

38 B. O. Nwabueze, Presidentialism in Commonwealth Africa (1974), p. 138.
} 
those of his agents was possible; such control as there might be could only come from Metropolitan institutions, but their role in this respect was not likely to be constant or regular as their main interest was confined to France itself.

In both Kenya and the Ivory Coast, a rapid decentralisation of Executive Power is in evidence towards the very end of the colonial era. In each case the Governor, though he remains in law the holder of the Executive Power at the local level, in fact gradually surrenders power to an elected Executive Authority supported by an elected Assembly. Thus, at independence ${ }^{39}$ the Governor's disappearance leaves behind a Parliamentary Government based on the Westminster or French model as the case may be. At this stage the official policy of the nationalist Government is to safeguard the Constitution and to preserve the inherited principles and procedures of public law.

Against this background one might have expected several principal factors to have an influence upon the subsequent course of constitutional development: (i) the transplanted principles of public law; (ii) the colonial experience; (iii) the needs of practical politics; (iv) traditional ideas and practices (while these had played little part in the organisation of the colonial State, some of them might now be restored in the search for ways of legitimation for the governmental process). The mutual interaction of (at least some of) these factors might be expected to produce specific institutional patterns of interest to comparative study.

\section{THE STRUCTURE OF THE POST-INDEPENDENCE EXECUTIVE AUTHORITY}

Our interest in this Section is both methodological and utilitarian: methodological in so far as we address ourselves to a cardinal aspect of comparative inquiry, namely, the structure of the institution; utilitarian inasmuch as we lay the basis for a treatment of the second crucial theme of the comparatist, namely, the functioning of the institution ${ }^{40}$.

As alluded to earlier, the structure of the African Executive Authority at independence is, in general, modelled on the tradition of the former colonising power. Several causes may be advanced for this tendency. Colonial possessions tend to be wanting in traditions of centralised government, there of ten having never been a unified State of the modern kind prior to the advent of colonialism. Even though over the colonial period an enlightened and dependable body of native personnel may have sprung up, this generally fails to arrive at any consensus on the basis of which a constitutional philosophy might be founded. It is rarely possible to evolve such a philosophy prior to independence because in nearly all cases the colonial authorities have placed varying degrees of restriction on local political activity, the colonial order, an imposition from without, being essentially inconsistent with such activity. Thus, at independence the nationalist régime often has little acquaintance with any constitutional tradition but that of the "mother-country" (and, of course, that of the colonial period ${ }^{41}$ ).

39 One year before independence (under the Constitution of 1959) in the case of the Ivory Coast. In all the Républiques autonomes the Governor disappeared on attainment of internal autonomy, being replaced by a High Commissioner, a personal representative of the French President with no Executive responsibilities.

40 Cf. G. Heckscher, The Study of Comparative Government and Politics (1957), pp. 74-79; C. J. Hamson and T. F. T. Plucknett, The English Trial and Comparative Law (1952); K. Zweigert and H. Kötz, An Introduction to Comparative Law (trans. T. Weir) (1977), p. 4.

41 Cf. J. B. Ojwang, “Parliamentary Privilege in Kenya: The Role of an imported Constitutional Concept”, in University of Tasmania Law Review, 6(1) (1978), 73-74; S. A. de Smith, op. cit., pp. 68 ff.; F. D. Schneider, "The Study of Parliamentary Government in the Commonwealth", in Parliamentary Affairs, 14 (1960), 460. 
The notable exception to this syndrome was, of course, the United States of America, which emerged from colonial subjection with a united will manifesting itself in a highly stable Constitution. This may be simply explained; apart from the fact that the American settlers were people of great political consciousness (this accounted for their trans-Atlantic adventure), this attribute had not suffered much under colonialism as the arrival of independence was only the climax of a sustained attempt to win autonomy from Britain.

Under both the British and French Constitutions, the structure of the Executive Authority, the person or body entrusted.with the exercise of the Executive Power of the State, reflects one main concern: to avoid a concentration of power in the same hands. In each case this anxiety has its origin in historical experience, with the Stuart dynasty and the Ancien Régime, respectively. The Executive Authority, at the highest level, consists in two different persons entrusted with "mutually countervailing" powers. In Britain the daily conduct of government is performed by the Prime Minister and his Cabinet within a climate of goodwill and reverence symbolised by the "dignified" organ, the Monarchy. While the French Constitution, like that of Britain, provides for a dual Executive Authority, it does not draw quite so clear a line between the "efficient" and the "dignified" functions. The Executive Authority here consists of the President of the Republic, on the one hand, and the Government, composed of the Prime Minister and the Council of Ministers, on the other. Unlike the British Monarch, the French President plays an active role in the daily conduct of government, appointing the Prime Minister himself, apart from presiding at meetings of the Council of Ministers ${ }^{\mathbf{2}}$.

Kenya's Independence Constitution provided for a dual Executive of the British kind; indeed, the parallel was all the closer as this Constitution, in effect, introduced "Dominion" status under which the British Monarch was also Kenya's Head of State. Constituting the "dignified" organ, the Queen was represented by a Governor-General43, while the "efficient" organ consisted in a Prime Minister and his Cabinet, all members of the Legislature enjoying majority support in the House ${ }^{44}$. Although the two facets of the Executive Authority seemed to be but a replica of the Westminster style, however, a closer observation would have revealed profound differences. According to Bagehot the "dignified" organ derived its authority from its constant reality as the symbol of nationhood and of State leadership ${ }^{45}$. In relation to Kenya such a symbolic role had not only emerged precipitately, but in almost direct succession to the epoch of the Governor's omnicompetence. Further, the Monarch was not physically present and was represented only by an appointee who had himself no natural symbolic standing. Thus, the "dignified" aspect of the Independence Constitution appeared divorced from the fundamental assumption of the British Constitution. In Bagehot's conception, "Without [the Queen] in England the . . . English Government would fail and pass away46." If we transpose this link to the Kenyan context it becomes obvious that the absence of the "dignified" organ from the social life was likely, to say the least, to weaken considerably the "efficient" working of the Prime Minister and his Cabinet. This deficiency soon became apparent, and solution was sought by way of constitutional amendment and the incorporation of additional values into the body of public law.

42 M. Duverger, Institutions politiques et Droit Constitutionnel, 12th ed. (1971), Vol. 2, pp. 183-84.

43 Independence Constitution, Sched. 2 of the Kenya Independence Order in Council, S. I. No. 1968 of 1963, Arts. 31-33.

44 Independence Constitution, ss. 75 and 76.

45 W. Bagehot, The English Constitution (1963), p. 86.

46 Ibid., p. 82. 
A Senegalese scholar, Ibrahima Fall, describes the constitutional life of independent Africa as falling into three phases: "imitation of western tradition", "taking of stock", and "autochthony"47.

The arrival of the last phase in Kenya and the Ivory Coast would appear to have taken interesting, contrasting forms; in Kenya it came a year after the attainment of independence, being introduced by a series of constitutional amendments; and in the Ivory Coast it was embodied in the Independence Constitution itself. While in Kenya the Constitution was to be amended under the pressure of immediate need, that of the Ivory Coast seemed to based on a careful foresight of political trends; it was so flexible as to require no major amendment. Thus, from differing start-points the two countries set out to develop their own appropriate constitutional structures.

Republican status was introduced in Kenya by an amendment of the Constitution which established the Presidency, its incumbent being both Head of State and Head of Government. The President's term of office was tied to that of the National Assembly, from the membership of which he appointed his Cabinet. This change war rationlised, first, on the principle of autochthony:

[We] propose that strong national leadership be assured by the selection of a President who is Head of State and Head of Government, instead of the illusory arrangement in which you have a constitutional President and someone else as Head of Government. This arrangement is just not understood by our people . . . The historical process by which, in other lands, Heads of State, whether kings or Presidents, have become figureheads [is] no part of our African tradition. So in this respect we . . r reject the Westminster model ${ }^{48}$.

In the African social context, it was argued, the dignity of leadership inhered in its overall competence in all spheres of decision making rather than in its disintegration into lesser components. As regards the elective aspect of the Executive Authority the Government founded its case on a blend of traditional practices, empirical logic and a measure of eclecticism: The people are asked to elect a Parliament to be their spokesman and the instrument of their destiny. In our view it is nonsense for any part of their Government to be outside Parliament ${ }^{49}$.

The new Cabinet was rationalised on the basis both of foreign experience and of traditional ideas:

Here ... we seek out the modern constitutional form most suited to our traditional needs . . . Our people have always governed their affairs by looking to a Council of Elders elected and headed by their own chosen leader, giving them strong and wise leadership. That tradition i.e. [team government] - which is an Africanism - will be preserved in this new Constitution ${ }^{\mathbf{5 0}}$.

These developments, with regard to the structure of the Executive Authority, had the effect of drawing Kenya away from the traditional Westminster model and towards the French model in the form adopted in many of the former Overseas Territories.

The anomaly in which the francophone States of Africa had experienced the "imitation" [phase] of development earlier than usual may be explained on two main grounds: Firstly, the context in which France granted independence to her African colonies necessarily encouraged an early experimentation with the constitutional structure; apart from the fact that

\footnotetext{
47 I. Fall, "Le Droit constitutionnel au secours de l'authenticité et de la négritude: le serment du Président de la République, acculturation ou retour aux sources?”, in Annales africaines (1973), 205.

48 Minister for Justice and Constitutional Affairs, in House of Representatives, Official Report, Vol. 3 pt. 3 (7 Oct. 1964$)$ cc. 3881 ff.

49 Ibid.

50 Ibid.
} 
the "mother-country" herself had adopted a new Constitution only two years earlier, the African leaders, most of whom had served as deputies in French Parliamentary bodies at a time of grave government instability, were naturally anxious to install a powerful and potentially durable Executive Authority. Secondly, the Fifth Republican Constitution, having literally been disigned to suit the personality of General de Gaulle ${ }^{51}$, could hardly fail to impress upon the African leaders the vitality of the position of Président de la République in the political and constitutional life.

Thus, under the Ivory Coast's Constitution the Executive Authority was single, the President of the Republic symbolising the dignity of the State as well as heading the discharge of its "efficient" function:

The President of the Republic is the Head of State. He symbolises the national unity. He ensures respect for the Constitution. He assures the continuity of the State. He is the guarantor of the independence of the Nation and of the territorial integrity52. .

In spite of initial contrasts, when the process of change did begin in Kenya it took the same direction as that taken by the Ivory Coast. The concept of strong and wise leadership convassed by the Kenya Government was strikingly reminiscent of de Gaulle's Bayeux proposals ${ }^{53}$ of 1946, which were incorporated in the Constitution of 1958, and the essence of which was the concentration of powers upon the Presidency; but Kenya's new Executive structure was more similar to that of the Ivory Coast as well as of those former Overseas Territories which had adopted the single rather than the dual leadership.

While Kenya, in making the post-independence constitutional changes, was concerned only with domestic problems of State organisation, its course of action had a wider significance for purposes of comparative inquiry. Even as she retained important aspects of the transplanted body of public law, Kenya was subscribing to a new approach which had been originated by the first African States to gain independence in the period beginning with the year 1957 and ending with 1961. This approach has been characterised as "neo-Presidentialism" its upshot being a match of the American Presidential system and the Westminster model which extracts from each stream only those aspects which will serve to fortify the position of the Executive Authority in relation to the other organs of government ${ }^{54}$.

Although the foregoing aspects reveal considerable similarity in the structure of the Executive Authority in the two countries under study, there are also notable contrasts. For instance, while the Kenyan President has the closest possible link with Parliament, that of the Ivory Coast is not himself a deputy and his entire Government is tightly insulated from the National Assembly by a rigid conception of the separation of powers doctrine ${ }^{55}$. Another important contrast concerns the office of Vice-President, for which the Ivory Coast makes no provision, while the Kenya Constitution provides that the Vice-President "shall be the principal assistant of the President in the discharge of his functions"56. In the Ivory Coast a convention has evolved since independence whereby the President appoints one of his Ministers to discharge the ordinary functions of his office during the former's absence.

\footnotetext{
51 M. Debré, "La nouvelle Constitution", in Revue française de science politique, 9 (1959), 7-29; G. Burdeau, "Lá Conception du Pouvoir selon la Constitution française du 4 octobre 1958”, in Revue française de science politique, 9 (1959), 87-100.

52 Law No. 60-356 of 3 Nov. 1960 (Journal officiel de la République de Côte d'Ivoire - Actes du Gouvernement, 4 Nov. 1960, p. 1271), Art. 8.

53 de Gaulle, "Discours du Général de Gaulle à Bayeux", in nevue française de science politique, 9 (1959), $188-92$.

54 J. Buchmann, "La tendance au Présidentialisme dans les nouvelles Constitutions négro-africaines", in Civilisations, 12 (1) (1962), 46-74.

55 Constitution of the Republic of the Ivory Coast (1960), Art. 25.

56 Constitution of Kenya (Act No. 5 of 1969), s. 15 (3).
} 


\section{E. THE NATURE AND SCOPE OF THE EXECUTIVE POWER IN THE POST-IN- DEPENDENCE PERIOD}

By the Executive Power, Montesquieu said, "[the prince or magistrate] makes peace or war, sends or receives ambassadors, keeps the peace, prevents invasions ${ }^{57}$." This was only a general way of describing the foremost characteristics of the Executive Authority as the main repository of the initiative of public decision making in any country. Such decisions fall at two recognisable levels; the more general level of broad policy formulation and the more closely defined level of the detailed implementation of policy ${ }^{58}$. At the first level one is mainly concerned with prerogatives as well as with such specific discretionary powers as may be conferred by the Constitution or by ordinary laws. At the second level one is primarily concerned with the exercise of a more limited kind of latitude, usually entrusted to subordinate agencies of the Executive Authority. There is, however, also a third level, though this is not as readily recognisable to lawyers as the other two: one is here concerned with the de facto influence upon the public institutions and functions which the Executive Authority may come to enjoy, thanks to personal peculiarities or the special historical circumstances which have accompanied the process of succession to leadership, what the French scholars have termed "the personalisation of power"59. This aspect of power deserves due mention in a study of law as it will often have a direct effect upon the "practical validity" of the law.

\section{PREROGATIVES AND RELATED POWERS}

In its historical sense the concept of "prerogative" belongs to the Common Law; and it refers to those residual governmental powers which are recognised by the Courts as inhering in but one person, the Monarch.

Under Kenya's Independence Constitution, most of the powers which would fall to the Monarch within the concept of prerogative were defined and specially consecrated. But as the British Queen was then also the Queen of Kenya, a question might be raised as to whether in relation to Kenya she had not lost the prerogative and now derived her powers solely from the written Constitution ${ }^{60}$. It might, indeed, be argued that the formal enactment of these powers had effectively abrogated them as prerogatives; for not only had they ceased to belong to the unwritten Common Law, but the Sovereign's legal right to act without fetters to her discretion had also been abrogated. Thus, although the normal powers of the prerogative kind were still exercisable it was henceforth more appropriate to regard them as special discretionary powers ${ }^{\mathbf{6 1}}$.

Under the Constitution the Executive Power was to be exercised by the Governor-General "either directly or by officers subordinate to him ${ }^{62}$." In specific terms he was empowered to appoint the members of the Government, but as already mentioned, this power like that of dismissal was qualified to the extent that the Governor-General was to be guided by the concept of majority representation in Parliament ${ }^{63}$. Although the Governor-General's power of

\footnotetext{
57 De l'esprit des Lois (eds. J. P. Mayer and A. P. Kerr) (1970), Bk. XI Chap. 6, p. 168.

58 M. Duverger, Eléments de Droit public, 8th ed. (1977), p. 9.

59 L. Hamon and A. Mabileau, La personnalisation du Pouvoir (1964).

60 It is recognised under the British Constitution that royal prerogatives may be abrogated by the Legislature: Attorney-General v. De Keyser's Hotel, [1920] A. C. 508; R. v. Kent Justices ex p. Lye, [1967] 2 Q. B. 153.

61 Cf. E. Campbell, "Parliament and the Executive", in Zines (ed. Commentaries on the Australian Constitution (1977), pp. 88-89.

62 Independence Constitution, s. 72 (1)

63 Ibid., ss. 75, 77, 81, 87.
} 
pardon was described as a "prerogative", it was nevertheless specifically regulated and made exercisable after consultation with "an Advisory Committee on the Prerogative of Mercy $^{64}$." In Britain by contrast, the Queen's power of pardon is a Common Law prerogative exercised by her over her Courts and in her own discretion ${ }^{65}$. While the right to prorogue Parliament was unfettered, the Governor-General's power of dissolution was made subject to the disposition of the Parliamentary majority on the same lines as those obtaining in British practice ${ }^{66}$.

The structural changes in the Executive Authority which took place following the attainment of independence are of special interest to us here, from the perspective of the nature and scope of the Executive Power. The eminent position accorded the Head of State, in the countries in reference as elsewhere on the continent, was to be matched by a corresponding grant of power. The situation was epitomised in an analogous context by the following remark of the Tanganyikan leader, J. Nyerere:

To us, honour and respect are accorded to a Chief, Monarch or President not because of his symbolism, but because of the authority and responsibility he holds. . . . Second, the President must not only carry the responsibility for the actions of government: he must also have the power to fulfil his responsibilities ${ }^{67}$.

The Kenyan President was invested with far-reaching powers, free of any significant constitutional limitations. Such powers may be considered under three sub-heads: (a) powers in relation to the Legislature; (b) powers in relation to the Executive establishment itself; (c) powers in relation to the Judiciary.

(a) Subject to the provision of the Constitution that there is to be at least one Parliamentary session in every year, the President has an unfettered discretion to prorogue the National Assembly "at any time" and to summon it to new session "at such place within Kenya . . a at such time as [he] may appoint", and he "may at any time dissolve Parliament ${ }^{68}$."

By contrast the Ivory Coast Constitution, with its conception of separation of powers, makes no provision for prorogation or dissolution, the life of the National Assembly and the duration of its sessions being defined by law and secured from intervention by the Executive Authority ${ }^{69}$. But this "limitation" has not been seen as a disadvantage by the Ivorian leaders; quite the reverse, as was affirmed by the then President-designate, Félix Houphouët-Boigny: "The Assembly must legislate and the Executive must govern. When the Assembly approves the Government's general program, it becomes obligated to give the Executive the means to carry it out ${ }^{70}$."

While the Kenyan President has the exclusive power of assent to Bills, it is not altogether clear whether he retains a right of veto. In line with the British practice, the Constitution provides:

Upon a Bill that has been passed by the National Assembly being presented to the President for assent, it shall become law and shall thereupon be published in the Kenya Gazette as $\mathrm{law}^{71}$.

64 Ibid., ss. $88,89$.

65 R. F. V. Heuston, Essays in Constitutional Law, 2nd ed. (1964), pp. 68-72.

66 Independence Constitution, s. 65.

67 J. Nyerere, "How much Power for a Leader", in Africa Report (Jul. 1962), 5 (emphasis added). This view is widely shared by other African leaders: A. R. Zolberg, One-Party Government in the Ivory Coast, Rev. ed. (1969), pp. 250-85.

68 Constitution of Kenya (Act No. 5 of 1969), ss. 58 (1) and 59 (1). A similar provision is to be found in other African Constitutions: Constitution of Malawi (1966), Arts. 44-46; Constitution of Botswana (1966), Arts. 91-94; Constitution of Zambia (Cap. 1), Arts. 92-94.

69 Constitution of the Ivory Coast, Arts. 29-31. It is provided, however, that Parliament may meet in extraordinary session at the behest of the President of the Republic (Art. 32); the President may also demand that Parliament meet as an enlarged committee in camera (Art. 34).

70 Zolberg, op. cit., p. 259.

71 Constitution of Kenya, s. 46 (3). 
By analogy with the convention of the British Constitution, one supposes that the President's "prerogative" here is only a formality. (In any case the Government has played the dominant role in the process of law-making, and, in view of its control over the individual Member of Parliament through party machinery, it seems hardly likely that a major controversy would arise in relation to the Presidential power of assent.)

The Ivorian President has a similar power, the Constitution providing that he is to sanction and promulgate the laws passed by Parliament within a specified period ${ }^{\mathbf{7 2}}$. There is the contrast, however, that the President in this case may, in effect, exercise a suspensive veto by requesting - a request which may not be refused - a second deliberation. The veto may be overriden but only by a majority of two-thirds of the total membership of the National Assembly $^{\mathbf{7 3}}$. The President may, further, delay the passage of a law in relation to which he has exercised such a veto by demanding that it be reconsidered only at the next ordinary session of the Assembly.

The President of Kenya is entitled "to address the National Assembly at any time he thinks fit" in his capacity as Head of State ${ }^{74}$. On such occasions he takes the "Chair of State", from which his address "shall be heard in silence and not followed by any comment or ques-

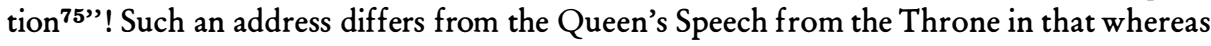
the latter is essentially a formality, performed within the concept of the "dignified" function, the former is subject to no limits of time or subject, and could be employed, at least in theory, as a device for the conduct of the ordinary process of government. A parallel provision is made in the Ivory Coast Constitution which, reproducing the French concept of the "right of Address" (le droit de message), provides:

The President of the Republic communicates with the National Assembly either directly or by a message read on his behalf by the President of the National Assembly, and such communications may not be made the subject of debate ${ }^{76}$.

This right, like it is in Kenya, could facilitate a simultaneous performance of both the "dignified" and the "efficient" functions.

While in both countries the Executive Authority enjoys wide powers of initiating the process of law-making, the specific provisions relating to these bear contrasts which correspond to those existing between the British and the French practice. Except in the sphere of finance, the Constitution of Kenya confers no special law-making function upon the Executive Authority, while that of the Ivory Coast goes further still, and, following in the French tradition, stipulates in clear terms the subjects which come within the competence of the National Assembly, all the rest being reserved to the exclusive sphere of the Executive ${ }^{77}$.

Also derived from French law is the provision of the Ivorian Constitution which empowers the President of the Republic to submit a Bill to referendum and thereafter promulgate it as law without recourse to the ordinary legislative procedure ${ }^{78}$. The Constitution of Kenya has no similar provision.

72 Constitution of the Ivory Coast, Art. 13

73 A similar provision is t obe found in the Constitutions of most of the former French African colonies: eg. Constitution of the Republic of Senegal (1963), Arts. 61 and 62.

74 Constitution of Kenya, s. 52 (a). A similar provision is made in other African countries: Constitution of Zambia, Art. 83; Constitution of Malawi, Art. 37; Constitution of Botswana, Art. 35.

75 Standing Orders of the National Assembly (1974), para. 14.

76 Constitution of the Ivory Coast, Art. 26, based on Art. 18 of the French Constitution of 1958; cf. Constitution of Senegal, Art. 68.

77 Constitution of the Ivory Coast, Art. 44.

78 Ibid., Art. 14; cf. Constitution of Senegal, Art. 46. 
(b) In the post-independence constitutional amendments the Kenyan President was given full powers of appointment and dismissal in Government ${ }^{79}$. A similar position obtains under the Ivory Coast Constitution, the President of the Republic in his capacity as "Head of the Administration" naming and terminating all public-office holders ${ }^{\mathbf{8 0}}$.

(c) Subject to specified qualification requirements and to a special procedure of dismissal, the President of Kenya has an unfettered discretion in the appointment of the Chief Justice, while he is required to consult with an independent body, the Judicial Service Commission, before making other appointments to the Bench ${ }^{\mathbf{8 1}}$. The corresponding powers of the Ivory Coast Executive are couched in wider terms, the President of the Republic being designated as "guarantor of the independence of the judges ${ }^{82 "}$ ", in which capacity he makes appointments to the Bench acting with the advice of the Minister of Justice and of the Superior Council of the Magistrature ${ }^{83}$. In both countries the Head of State may intervene in the Judicial function by giving a pardon to convicted persons ${ }^{84}$.

\section{THE POWERS OF SUBORDNINATE AGENCIES}

While it is for the superior organs of the Executive Authority to exercise powers entailing high discretion, the execution of such decisions is often left to the ordinary departmental administration.

In practice the powers exercised by the various agencies in the implementation of Government decisions are not always "limited"; the position may differ from one country to another. In Britain such powers are truly limited in the sense that they generally derive from Ministerial or departmental regulation which provide a definite framework for their control by the Courts, apart, of course, from the availability of Parliamentary control. That is not the case in France, the Ivory Coast or Kenya, countries with extensive networks of "Provincial Administration", within the ambit of which the widest discretion is of ten exercised by public servants.

In Kenya, as already seen, the colonial era left behind a powerful structure of State administration which invested public servants with crucial decision-making responsibilities. This heritage has had an obtrusive impact upon the post-independence social life, in particular, as regards public order, in which sphere the senior members of the Provincial Administration have exercised far-reaching powers ${ }^{85}$. The position is hardly different in the Ivory Coast, where the Prefects and Sub-Prefects effectively carry the daily authority of Government in the départements, the relevant law providing that:

79 Constitution of Kenya, ss. 17, 18, 24, 25, 106-108; Ghai and McAuslan, op. cit., pp. 246-50; J. B. Ojwang, "Kenya and the Concept of Civil Service Political Neutrality", in The Indian Journal of Public Administration, 24 (2) (1978), 434-35.

80 Art. 17.

81 Constitution of Kenya, s. 61.

82 Constitution of the Ivory Coast, Art. 59; the position in France: Duverger, Institutions politiques et Droit constitutionnel, op. cit., pp. 199-201.

83 Constitution of the Ivory Coast, Art. 61.

84 Constitution of Kenya, ss. 27 and 29 (see also the Constitution of Kenya (Amendment) (No. 2) Act, 1975); Constitution of the Ivory Coast, Art. 20. (Cf. Constitution of Zambia, Art. 60; Constitution of Malawi, Arts. 60 and 61; Constitution of Botswana, Art. 56.) In the present category may be included the Governments emergency powers. In Kenya the Preservation of Public Security Act (Cap. 57) empowers the President to restrict the enjoyment by an individual of certain guaranteed rights on grounds of State security: J. B. Ojwang and G. K. Kuria, "The Rule of Law in General and Kenyan Perspectives", in Zambia Law Journal, 7-9 (1975-77), 122-26. The corresponding position in the Ivory Coast is stated in Art. 19 of the Constitution which, reproducing Art. 16 of the French Constitution, provides: "When the institutions of the Republic, the independence of the Nation, the integrity of its territory or the fulfilment of its international commitments are threatened by a clear and present danger, the President of the Republic takes the exceptional measures necessitated by these circumstances..."

85 The Public Order Act (Cap. 56); the Outlying Districts Act (Cap. 104); the Special District (Administration) Act (Cap. 105) the Chief's Authority Act (Cap. 128); the Societies Act (Cap. 108). 
The Prefect may take any coercive measure in the interests of the security of the State, the safety of individuals and the wholesomeness and the peace of the public, the observance of national patriotism ${ }^{\mathbf{8 6}}$.

\section{THE EXTRA-JURIDICAL POWER}

In both Kenya and the Ivory Coast, the general direction of constitutional development has been determined by certain dominant issues of politics. In Kenya these have been, the politics of colonialism in the first half of the century and the politics of multi-racialism in the last decade of colonial rule; in the Ivory Coast the politics of assimilation in the early part of the colonial period, and, thereafter, the politics of autonomy; in the post-independence period the singular influence in each case has been the charismatic leadership of the first Head of State. But, in the later years, charisma as a source of power has coincided with yet another important political development, namely, the advent of the single party.

Charismatic Leadership. The attainment of independence in each African country that had experienced colonial rule presented the new State with one fundamental challenge, that of legitimacy. This problem had not existed in colonial times inasmuch as the colonial authorities had made no pretensions of legitimacy. For the independent Governments, however, it was vital to lay a new basis of civil obedience and public order, founded upon a claim to legitimacy.

According to Max Weber ${ }^{87}$ an authority may gain legitimacy in at least one of three ways: (a) through tradition; (b) through a public recognition of the rational-legal character; (c) through charisma. It will be appreciated that in the case of Kenya and the Ivory Coast the first two methods were inapplicable and only the third was ${ }^{88}$. Since these countries were breaking off from a past of authoritarisanism there could not have been any tradition left to sustain the concept of legitimacy; in the same way the rational-legal character was lacking as the scope of constitutional debate had in each case been confined to but a slim elite, apart, of course, from the fact that the bulk of the population was illiterate. Inevitably, therefore, national direction had to come from someone who, in the public's eye, was "endowed with great personal worth . . . [maybe] . . . from God ${ }^{89 ",}$, someone "blessed with supernatural and extraordinary powers unbeknown to other mortals ${ }^{\mathbf{9 0}}$."

In Kenya the undisputed natural leader was Jomo Kenyatta, who apart from fulfilling the Weberian test also sported his own unique style of politics which invariably won him the popular acclaim ${ }^{91}$. A similar recognition was accorded Félix Houphouet-Boigny in the Ivory Coast.

It is hardly surprising, therefore, that the course of constitutional development in both States in the last decade and a half or so has closely reflected the personalised authority of the Founding Father.

The Sole Political Party. The charismatic leadership and the single party performed complementary roles in the process of power concentration. As alluded to above, charisma is only a start-point, which ought ideally to be transformed into relatively impersonal yet more

\footnotetext{
86 Law No. 61-84 of 10 April 1961 (relating to the functioning of the Departments, the Prefectures and the Sub-Prefectures).

87 M. Weber, On Charisma and Institution Building - Selected Papers (ed. S. N. Eisenstadt) (1968), pp. 11-17.

88 Cf. D. A. Low, Lion Rampant: Essays in the Study of Imperialism (1973), pp. 94-99.

89 S. M. Lipset, The First New Nation: The United States in Historical and Comparative Perspective (1963), p. 17.

90 M.-P. Roy, Les régimes politiques du Tiers monde (1977), p. 580.

91 On this second aspect of charisma see A. R. Zolberg, Craeting Political Order: The Party States of West Africa (1966), p. 138.
} 
viable institutions of government (the alternative is loss of the charisma itself in the longer run $^{92}$ ). In Africa the sole party has generally been resorted to as an expeditious device for stabilising the institutions of government in the light of declining charismatic authority ${ }^{\mathbf{9 3}}$. Kenya and the Ivory Coast, although claiming to be only de facto one-party States, have effectively legalised this position in important particulars. Under the Constitution of Kenya nobody may participate in general election without party approval ${ }^{94}$, while in the Ivory Coast it is provided by law that all candidates for Presidential or Parliamentary election are to be those sponsered by "a legally constituted party or grouping ${ }^{95}$." In either case the party acquires a juridical character, and the questions of power in this sphere become equally relevant to the nature and scope of the Executive Power as a strict constitutional matter, the Head of State being in each instance also the head of the Party ${ }^{96}$. The extensive influence deriving from this source can hardly be underestimated in a constitutional study such as the present one.

\section{F. A COMPARATIVE REFLECTION}

We submitted at the beginning that "although one may study [the institutions of public law of the new African State] in their own right as organs of governmental authority, it is important to recognise that none of them . . . could approximate to the Executive organ in terms of power and influence." The immediate realisation arising from this study is that the Executive Power and influence pervades and dominates the public life in the countries in question; that this experience boasts an historical continuity from the very beginning of the modern State, with the advent of colonialism, to the present. If the omnipotent Executive was essential to the colonial order by the very definition of that order, it has proved equally vital to the postindependence régime as a device for creating and developing a nation.

In these circumstances it is hardly surprising that the critical parameter in the development of public law in post-colonial Africa has been, not the British or French principles of government as such, nor even of the local tradition, nor indeed of any single factor; but rather, of the ill-defined problems of leadership in a novel context of development, which have confronted virtually the entire continent. It is on the basis of this common denominator that each State has looked to its historical past, to the former "mother-country", to the traditional experience, to new styles of political logic, etc., for reinforcing strains of public law; the effect being that though these States may cling to many western institutions and to their attendant procedures and terminologies, these are unlikely to retain the same signification which they have borne under the original models. What has taken place is a selective process of transplantation, the ultimate goal of which is to assemble a new tradition of public law. The comparative method is invaluable, to adopt the terms of D.G.T. Williams, "both as an aid to understanding different constitutional systems and as a means of widening our appreciation of particular problems ${ }^{97}$." Apart from seeking to shed light on an aspect of the functioning of the British and French systems of law as applied in Africa, we have attempted

\footnotetext{
92 Roy, op. cit., p. 582.

93 Roy, op. cit., p. 36.

94 S. 5 (3) (a).

95 Law No. 60-359 of 7 Nov. 1960; Constitution of the Ivory Coast, Art. 7.

96 G. Tixier, "La personnalisation du Pouvoir dans les Etats de l'Afrique de l'Ouest", in Revue de Droit public et de la science politique en France et á l'Etranger, 81 (1965), 1146 ff.; H. Deschamps, Les institutions politiques de l'Afrique noire (1962), p. 119.

97 D. G. T. Williams, Book Review (A. S. Mathews, The Darker Reaches of Government: Access to information about Public Administration in three Societies (1978), in The Cambridge Law Journal (1979), 404-405.
} 
to illustrate the general problem of the nature and scope of the Executive Power. If, as seems obvious, the main problem of public law today is how to design effective controls for the Executive Power, the discussion in this article, it is submitted, leaves no doubt as to the urgency of this matter in Africa. This is particularly so in view of the fact that the States in question have since independence adopted Executive Power structures the susceptibility to control of which, by traditional western techniques, is not yet clear. 


\section{The English Poor Law and Egalitarian Agrarian Reforms in the Third World By HaRTMut ElSENhans}

The follwing article shows that the English Poor Laws have been an effective instrument of retransfer of income to poors. The article refutes neoliberal and marxist theory of previous accumulation as rise in surplus by cheapening labour. Instead of this structure, the English previous accumulation has been caracterized by a rise of real income for popular masses. The Poor Laws are one example of the rise in popular incomes.

The article starts from the observation of Georgescu-Roegen that in undeveloped societies with average product above subsistance level marginal product of labour may be subsistance level. In that case, the intrusion of market relations and the maximization of profit will lead to unemployment. There will be only employment for those that for that part of the labour force, which given the existing quality and quantity of equipment and soil fertility will produce a surplus. This surplus actually may be very high. If this surplus is taxed the private sector will not diminish employment, because the rate of profit will be highest at the same volume of employment as before. Nevertheless the tax revenu can be used for subsidizing those workers beyond the point of profit maximization. By cheapening the workers whose marginal product is below subsistance level employment and total product can be raised, whereas at the same time the part of profits in total income diminishes.

The article shows then that an egalitarian agrarian reform may have the same consequences in the Third World today and tries to elucidate the notion of structural heterogeneity as divergence of sectoral factor productivities, requiring the control of foreign economic relations and the development by using diminishing unit costs in mass production lines.

\section{The Nature and Scope of the Executive Power in English and French-Speaking Africa: A Comparative Perspective}

\section{By J. B. OJwang}

This article focuses its attention on the character of the executive power in new African States. The legal framework in which this power is exercised takes differing forms depending on the particular model whereupon a given constitution has been drawn up. The preponderant juridical inflences in African constitition - making have been those of Great Britain and France - these two having been the chief colonial powers (through which link they were able to bequeath their own concepts of public law to the new States at independence). It is one of the primary objects in this study to highlight the relationship between constitutional theory and the reality of power; this aspect is brought out by a comparative treatment which aims to facilitate a simultaneous glance at the part played by the differing lines of western influence. It is also an object of the inquiry to assess the extent to which transplantation of laws, with regard to the domain of constitutional law, has been a reality in Africa. The study sets out with several propositions, one of these being that, the course of constitutional development in the former British and French colonies was destined to take an essentially similar direction, owing to the fundamental similarity of economic, social and political circumstances which typified thes countries - and that notwithstanding their strikingly dissimilar juridical foundations.

The original factors of similarity are set out in a historical account on two selected countries Kenya and Ivory Coast. The post-independence development of the executive structure, 
both at law and in general political character, is then discussed in comparative perspective. This is followed by a fairly detailed treatment, again in comparative perspective, of the nature and scope of the executive power. This aspect is considered, first, under the head of prerogative and other superior discretionary competence; secondly, with regard to the subordinate administrative agencies of the Executive; and lastly, in terms of the extrajuridical competence (or capacity?) which the executive organ may come to enjoy, not so much in virtue of legal prescriptions, but, rather, purely due to the historical circumstances wherein the structure and process of leadership have been shaped and in which, in particular, accession to power has taken place.

It would emerge from the study that, since independence, in anglophonic as in francophonic Africa, a fundamental transformation of function, vis-à-vis the western-derived constitutional concepts, has come about. While the basic constitutional terminology remains the same, the constitutional structure has been readapted to the dictates of a new power-situation - a situation largely owing to common problems of nation building and economic development. In this new power structure the Executive is the all dominant organ, a fact which at once poses the most difficult questions in relation to any attempts at power control; the western-derived control procedures, although still forming part of the constitutional landscape, were obviously not designed with the apparent trends in view!

\section{The Development of the Republic of Malawi: A Strategy between Voluntary Depend- ency and Authoritarian Satisfaction of Basic Needs \\ By Gerald Braun and Heribert Weiland}

The development of the Rupublic of Malawi is judged variously: While the UN classifies Malawi as a least developed country, other development experts see this mini-state as a prosperous police state or as "la Suisse d'Afrique".

The article attempts to show empirically the external dependency of Malawi by using different dependency concepts, such as external sensitivity, unequal exchange, external determination, unequal cost-benefit distribution.

The authors illustrate that all forms of dependency can be demonstrated empirically. They note that Malawi's colonial dependence on Great Britain has been substituted by a new dependence on the Republic of South Africa.

This dependence, however, is very much different from the excolonial relationships of other African states, because it has caused a transfer of resources in favour of Malawi. This paradoxical development is due to a strategy of voluntary dependency, which has been pursued by the authoritarian leader of Malawi, President Dr. Kamuzu H. Banda. It is this aspect of voluntary dependency, which is not sufficiently seen and explained by the economically biased dependency concepts.

Although this voluntary dependency proved to be very profitable for the state bureaucracy in Malawi, it also did not harm the mass of the population. On the contrary, according to the Physical Quality of Life Index, Banda's development policy has led to a degree of satisfaction of physical basic needs for the masses in Malawi which ranks significantly above the level of comparable African states. If one tries to generalize these findings, it seems that authoritarian basic needs strategies can lead to a satisfaction of the physical needs of the population. However, it is doubtful whether the authoritarian satisfaction of physical needs can solve the problem of underdevelopment in the long run. There is empirical evidence that, with rising standards of living, the demands for non-material goods - especially for participation - increase as well. 